\title{
Yabancı Dil Olarak Türkçe Öğretiminde Yazma Becerisi Tutum Ölçeği: Bir Ölçek Geliştirme Çalışması *
}

\section{Scale of Attitude towards Writing in Turkish as a Foreign Language: A Scale Development Study}

\author{
Öğr. Gör. Dr. Ömer Faruk KADAN (iD), Prof. Dr. Bülent ARI iD 2
}

\begin{abstract}
$\ddot{O} z$
Bu çalışmanın amacı, yabancı dil olarak Türkçe öğrenen öğrencilerin Türkçe yazmaya yönelik tutumlarını belirlemeye yönelik bir ölçek geliştirmektir. Bu amaçla, araştırmacı tarafından literatür taraması yoluyla 50 maddeden oluşan madde havuzu oluşturulmuştur. Uzman görüşleri doğrultusunda madde havuzundaki 3 madde atılarak 47 maddeye indirgenmiştir. Ayrıca, ölçekte bulunan 4 madde anlam karmaşasına yol açabileceği için uzman görüşleri doğrultusunda ifade olarak düzeltilmiştir. Çalışma grubu, toplamda Türkçeyi yabancı dil olarak öğrenen 377 öğrenciden (201 kadın ve 176 erkek) oluşmaktadır. 2017-2018 akademik yılında Hatay ilinde Türkçeyi yabancı dil olarak öğrenen 128'i kadın, 109'u erkek olmak üzere 237 öğrenci çalışmanın ilk aşaması olan pilot uygulamada; 73 kadın ve 67 erkek olmak üzere 140 öğrenci ise ikinci aşama olan asıl uygulamada çalışma grubunda yer almıştır. Ölçeğin yapı geçerliğini sağlamak için açımlayıcı ve doğrulayıcı faktör analizi yapılmış; güvenirliğini sağlamak için ise Cronbach Alpha iç tutarlık katsayısı hesaplanmıştır. Yapılan faktör analizi sonucunda toplam 20 maddeden oluşan 3 faktörlü ölçek elde edilmiştir. Ölçekteki faktörler; "yazmaya genel bakış”, yazmada yetersizlik” ve "yazmada yeterlilik" şeklinde belirlenmiştir. Ölçeğe "Yabancı Dil Olarak Türkçe Öğretiminde Yazma Becerisi Tutum Ölçeği” adı verilmiştir. Ölçeğin Cronbach Alpha iç tutarlılık katsayısı 0.653 olarak bulunmuş ve bu nedenle oldukça güvenilir olarak yorumlanmıştır.
\end{abstract}

Anahtar Kelimeler: Yabancı dil olarak Türkçe, yazma becerisi, tutum ölçeği

Makale Türü: Araştırma

\begin{abstract}
The aim of this study was to develop a scale for determining students' attitude towards writing in Turkish as a foreign language. For this purpose, an item pool with 50 items was generated via literature review. 3 items were removed after expert opinion. Additionally, 4 items were revised in line with expert opinion in order not to cause ambiguity. The study group consisted of 377 students (201 females and 176 males) learning Turkish as a foreign language. 237 Turkish as a second language students, 128 females and 109 males, studying in Hatay in 2017-2018 academic year were included in pilot study. Furthermore, 140 students, 73 of whom were females and 67 of whom were males, were included in the main study. Exploratory and confirmatory factor analyses were performed to ensure construct validity of the scale, and Cronbach's Alpha coefficient was calculated for providing reliability. As a result of the factor analyses, a scale with 3 components and 20 items was obtained. The components were defined as "writing overview", "incompetence in writing" and "competence in writing". The scale was named as "Scale of Attitude towards Writing in Turkish as a Foreign Language". The Cronbach's Alpha coefficient of the scale was found to be 0.653 ; thus, it was regarded as quite reliable.
\end{abstract}

Keywords: Turkish as a foreign language, writing skill, attitude, scale of attitude

Paper Type: Research

\footnotetext{
*Bu çalışma, 1 nolu araştırmacının "5E Öğrenme Modelinin Türkçeyi Yabancı Dil Olarak Öğrenen Öğrencilerin Yazmaya Yönelik Tutum ve Yazma Becerilerine Etkisi” adlı doktora tez çalışmasından geliştirilmiştir.

${ }^{1}$ Hatay Mustafa Kemal Üniversitesi, Yabancı Diller Yüksekokulu, ofkadan@mku.edu.tr

${ }^{2}$ Hatay Mustafa Kemal Üniversitesi, Eğitim Fakültesi, bari@ mku.edu.tr
}

Atıf için (to cite): Kadan, Ö. F., \& Arı, B. (2021). Yabancı dil olarak Türkçe öğretiminde yazma becerisi tutum ölçeği: Bir ölçek geliştirme çalışması. Afyon Kocatepe Üniversitesi Sosyal Bilimler Dergisi, 23(4), 1322-1333. 


\section{Giriş}

Genel olarak dört temel dil becerisi olduğu ifade edilmektedir. Bunlardan okuma ve dinleme anlamaya ilișkin beceriler; yazma ve konuşma ise anlatıma ilișkin beceriler olarak ifade edilmektedir. Anlatıma ilişkin becerilerden biri olan yazma, çok önemli olmakla birlikte kazanılması zor bir beceri olarak değerlendirilmektedir. Temizkan'a göre (2018, s. 143) yazma; hayal, duygu, düşünce gibi unsurların açık ve net bir biçimde yazılı olarak anlatılmasıdır. Türkel (2011, s. 14) yazmayı; "en basit anlamıyla duygu ve düşünceleri yazıyla anlatmaktır" şeklinde tanımlamıştır. Göçer (2010, s. 178) yazmayı, belirli bir konuda his, hayal veya özgün düşünceleri belirli bir düzen ve bütünlük içerisinde yazılı hale getirme şeklinde tanımlamıştır. Yazmayla ilgili yapılan tüm bu tanımlardan yola çıkarak onu; duygu, düşünce, kavram veya olguların birtakım semboller aracılığıyla yazılı olarak ifade edilmesini gerektiren karmaşık bir süreç şeklinde ifade etmek mümkündür. Fosnot (1989, s. 59) da yazmayı bir süreç olarak nitelemiştir.

Yazma, kuşkusuz karmaşık bir süreçtir. Çünkü tecrübelerin duygu ve düşüncelere yön vermesi, onların da zihinde birtakım işlemlerden geçerek tekrar yazıya aktarılması gerekmektedir. Yani, yazma eyleminin gerçekleşebilmesi için duygu ve düşüncelere ihtiyaç vardır. Duygu ve düşünceler ise bireyin önceden tecrübe ettiklerinde, gördüklerinde, duyduklarında, tattıklarında, okuduklarında gizlidir. Ancak onlar sayesinde şekillenmektedir. Yabancı dil olarak yazma da aynı bağlamda düşünülmelidir. Yabancı dilde yazma becerisi, bireylerin mevcut hedef dil yeterliliklerini ortaya koyabilmesi ve değerlendiricilerin bunu somut olarak görebilmesi bakımından son derece önemlidir. Bazı bireyler yabancı dilde konuşmaya çekindikleri için duygu ve düşüncelerini yazarak daha rahat ifade edebilmektedir.

Bireylerin yabancı dilde okudukları, duydukları, gördükleri şeyler onların hedef dilde yazmalarını yönlendirmektedir. $\mathrm{Bu}$ yönlendirmenin sebebini, düşüncelerin bu doğrultuda şekillenmesine bağlamak mümkündür. Bir başka deyişle, görülen, duyulan veya okunan şeyler bireyin düşüncelerine yön vermektedir. $\mathrm{Bu}$ düşünceler ise bireyin anlatımını ve yazmasını biçimlendirmektedir. Yeni karşılaşılan durumlar, mevcut bilgilerle ilişkilendirilmekte ve bu ilişkilendirme yoluyla düşünceler yazıya dökülmektedir. Yazma, beyinde yapılandırılan bilgilerin yazılı olarak ifade edilmesi (Güneş, 2007, s. 159); duygu, düşünce, yazılı olarak aktarılmasıdır (Göçer, 2012, s. 186). Bu aktarımın niteliği bazı değişkenlere göre belirlenmektedir. Bu değiş̧kenlerden biri de tutumdur. Bireylerin yazmaya yönelik tutumları yazının niteliğini doğrudan etkileyebilmektedir.

Thurstone (1928, s. 531) tutumu, belirlenmiş herhangi bir konuda bir insanın eğilimleri, duyguları, önyargıları, önceden şekillenmiş düşünceleri, korkuları, tehditleri ve inançlarının genel toplamı olarak açıklarken Hillson ve Murray-Webster $(2004$, s. 3) ise onu bir uçağın izlediği rotaya benzeterek durumlar için seçilmiş tepkiler şeklinde tanımlamıştır. Brown, Manogue ve Rohlin (2002, s. 704), tutumların değiştirilebileceğini ve bunun kişisel tecrübeler, kişisel tecrübelerin yansıması, grup etkileşimi, grup aidiyeti, mesleki kimlik, ikna gibi unsurlar aracılığıyla gerçekleşebileceğini ifade etmişlerdir.

Bireylerin tutumlarının değiştirilebileceğini bilmek çok önemlidir. Bu sayede bireylerin sahip oldukları olumsuz tutumların düzeltilmesi yolunda çalışmalar yapılabilir. Elbette bunu yapabilmek için öncelikle bireylerin tutumlarının ne düzeyde olduğunu tespit etmek gerekmektedir. Geçmişte, tutumların ölçülebilir olup olmadığı konusunda anlaşmazlıklar olsa da Thurstone, 1928 yılında gerçekleştirdiği çalışmasında, tutumun ölçülebileceğini ortaya koyarak sosyal psikolojideki en önemli yapılardan birinin kapılarını açmıştır. Tutumların ölçülmesinin eğitim sürecinin başında ve sonunda önemli olduğu ifade edilmiştir (Balcı, 2009, s. 269).

Tutumları ölçmenin farklı yolları bulunmaktadır. Bazen doğrudan bireylerin gözlemlenmesi ve belirli ölçütlere göre bu gözlemin değerlendirilmesi; bazen yazılı veya sözlü testler, denemeler veya kısa cevap soruları gibi geleneksel yöntemlerin kullanılması; bazen ise 
Likert tipi ölçekler, anket veya envanter gibi öz-bildirim ölçeklerinin uygulanması yoluyla bireylerin tutumlarının ölçülebileceği ifade edilmiştir (Brown, Manogue ve Rohlin, 2002, s. 706). Bireylerin tutumlarını ölçebilmek için var olan bir ölçek kullanılabilir veya yeni bir ölçek geliştirilebilir. Ölçme aracı kullanırken, ölçeğin ölçülmesi hedeflenen tutumu ölçüp ölçmediğine, geçerlilik ve güvenirliği sağlayıp sağlamadığına ve hedef kitlenin seviyesine uygun olup olmadığına bakılması gerektiği ifade edilmiştir (Henerson, vd., 1987'den akt. Balc1, 2009, s. 269). Bu bağlamda, tutum ölçeklerinin bu özellikler doğrultusunda geliştirilmesi gerekmektedir.

\section{Araştırmanın Amacı ve Önemi}

Bireylerin yazmaya yönelik tutumlarını belirlemek, onların yazma başarılarının geliştirilmesi bakımından önemlidir. Çünkü bazen yazma başarısı düşük olan bireylerin yazmalarının önündeki tek engel, onların psikolojik hazırbulunuşluklarını ifade eden tutumlarının düzeyidir. Yazma becerisine yönelik fiziksel hazırbulunuşlukları tam olan bu bireylerin, motivasyon ve tutum gibi psikolojik unsurlardaki yetersizlik nedeniyle iyi yazamadıkları düşünülmektedir. Tutum, bireylerin yazma becerisi kazanması ve bu becerinin geliştirilmesi sürecinde etkilidir (Temel ve Katranc1, 2019, s. 325). Yazmaya yönelik tutum, yazan kişinin kendini nasıl hissettiğiyle (mutlu veya mutsuz) ilgili duyuşsal eğilimidir (Graham, Berninger ve Abbot, 2012, s. 53). Yazmaya yönelik tutum, öğrencilerin yazılı anlatımda başarılı veya başarısız olma durumlarını önemli ölçüde etkilemektedir (Hess ve Wheldall, 1999, s. 15). Graham, Berninger ve Fan (2007, s. 518) daha olumlu tutuma sahip öğrencilerin, daha olumsuz tutuma sahip olan öğrencilere kıyasla daha sık yazmalarının ve daha fazla çaba sarf etmelerinin olası olduğunu ve bu durumun yazma başarısında bireysel farklılıklara yol açtığını ifade etmişlerdir. Bu nedenle bireylerin yazmaya yönelik tutumlarını belirlemek son derece önemlidir (Erdoğan 2012, s. 9).

Literatür incelendiğinde, yazmaya yönelik tutum ölçeklerine rastlanılsa da yabancı dil olarak Türkçe yazmaya yönelik herhangi bir tutum ölçeğine rastlanılmamıştır. Akbulut (2016), yüksek lisans tez çalışmasında "Yabancı Dil Olarak Türkçe Yazmaya Yönelik Tutum Ölçeği" kullandığını öne sürmüştür. Fakat ölçeğin Erdem (2007) tarafından ilkokul öğrencilerinin İngilizce yazma dersine yönelik tutumlarını belirlemek için geliştirilen ve Erarslan (2011) tarafından yabancı dil olarak İngilizce öğrenen üniversite öğrencilerinin yazma dersine yönelik tutumlarını ortaya çıkarmaya yönelik uyarlaması yapılan ölçek olduğunu belirterek ölçekte bazı değişiklikler yaptığını ifade etmiştir. Bir başka deyişle araştırmacı, İngilizce için kullanılan bir ölçeği Türkçe yazma için kullanmış ve bu isimle bir ölçek geliştirmemiştir. Oysa bu konuda ölçek geliştirilmesi için detaylı araştırmalara ve geçerlik-güvenirlik çalışmalarına ihtiyaç duyulduğu bilinmektedir. Yabancı dil olarak Türkçe öğrenenlerin yazmaya yönelik tutumlarını belirlemek, onların yazma becerilerinin gelişimi için son derece önemlidir. Bu nedenle bu çalışmada, Türkçeyi yabancı dil olarak öğrenen öğrencilerin Türkçe yazmaya yönelik tutumlarını ölçen bir ölçek geliştirilmesi amaçlanmıştır. Bu yönde alana katkı sağlaması bakımından araştırma oldukça önemlidir.

\section{Yöntem}

Çalışmada, ölçek geliştirme amaciyla deneysel süreç benimsenmiştir. "Deneysel süreçte literatür ya da uzman yaklaşımları sayesinde aday ölçek formu elde edilir ve hedef kitle ile benzer özellikler taşıyan bir örneklem grubuna deneme uygulaması yapılarak ölçek maddelerine ilişkin psikometrik özellikler belirlenerek ideal maddelerden nihai form elde edilir" (Yurdugül, 2005, s. 1). Deneysel süreç uygulaması için Hatay Mustafa Kemal Üniversitesi Sosyal ve Beşeri Bilimler Bilimsel Araştırma ve Yayın Etiği Kurulu'ndan etik izin alınmıştır (02.08.2018 tarih ve 10/01 nolu karar). Bu bölümde çalışma grubunun özellikleri, ölçek geliştirme süreci, veri toplama ve verilerin analizine ilişkin bilgiler sunulmuştur. 


\subsection{Katılımcilar}

Araştırmanın çalışma grubu 201 kadın (\%53.3) ve 176 erkek (\%46.7) olmak üzere toplam 377 kişiden oluşmaktadır. 2017-2018 akademik yılında Hatay ilinde Türkçeyi yabancı dil olarak öğrenen 128’i (\%54) kadın, 109’u (\%46) erkek olmak üzere 237 öğrenci, çalışmanın ilk aşaması olan pilot uygulamada çalışma grubunu oluştururken 73 kadın (\%52.1) ve 67 erkek (\%47.9) olmak üzere 140 öğrenci, ikinci aşama olan asıl uygulamada çalışma grubunu oluşturmuştur.

\section{2. Ölçek Geliştirme Süreci}

Tutum ölçeklerinin geliştirilmesinde bazı adımların takip edilmesi gerekmektedir. $\mathrm{Bu}$ çalışmada bazı araştırmacılar (Büyüköztürk, 2005; Karakoç ve Dönmez, 2014; Tezbaşaran, 2008) tarafından önerilen aşağıdaki adımlar izlenmiştir:

1) Madde havuzu oluşturulması

2) Uzman görüşü alınması

3) Pilot uygulama

4) Verilerin analizi (Faktör Analizi ve Güvenirlik Hesaplaması)

Madde havuzu oluşturulmasında, literatür taramasından faydalanılmıştır (Abbas, 2016; Aytan ve Tunçel, 2015; Bölükbaş, 2011; Davis, 1987; Elshirbini, 2013; Erdoğan, 2013; Göçer, 2014; Kear, vd. 2000; Lewis, 1998; Okasha ve Hamdi, 2014; O'neal, vd., 1984; Prickel, 1995; Soltani ve Kheirzadeh, 2017; Susar Kırmız1, 2009; Thomas, 1989; Tiryaki, 2013; Türkel, 2013; Wasson, 1993; Wynn, vd., 2000). Kaynaklar ve diğer araştırmacıların görüşleri detaylı olarak incelendikten sonra maddeler şekillendirilmiştir. Maddelerin belirlenmesinde; basit ve anlaş1lır bir dil kullanımı ve birden fazla yargı içermeme konusunda özen gösterilmiştir. Neticede 50 maddeden oluşan madde havuzu oluşturulmuştur. Bu maddelerde yer alan ifadelere öğrencilerin katılma siklıklarını belirlemek amaciyla "her zaman", "genellikle", "bazen", "nadiren" ve "hiçbir zaman" şeklinde beşli derecelendirme yapılmıştır. Bu nedenle ölçek 5'li Likert tipinde hazırlanmıştır. $\mathrm{Bu}$ madde havuzu, görüşlerini alabilmek amaciyla Türkçe eğitimi alanında çalışan ve TÖMER tecrübesi bulunan 3 alan uzmanı ile ölçme ve değerlendirme alanında çalışan 2 alan uzmanına sunulmuştur. Uzman görüşleri doğrultusunda ölçekten 3 madde atılmış ve ölçekteki madde sayısı 47 olmuştur. Diğer taraftan, ölçekte bulunan 4 madde anlam karmaşasına yol açabileceği ihtimaliyle uzman görüşleri doğrultusunda ifade olarak düzeltilmiştir. $\mathrm{Bu}$ şekilde ölçeğin kapsam ve görünüş geçerliği sağlanmıştır. Daha sonra yukarıda da özellikleri ifade edilen 237 öğrenci ile pilot uygulama gerçekleştirilmiştir. Pilot uygulamadan elde edilen veriler, açımlayıcı faktör analizine tabi tutulmuştur. Açımlayıcı faktör analizi sonucunda ölçekteki 47 maddeden $27 \mathrm{si}$ atılmış ve 20 madde ile ölçeğe son hali verilmiştir. Doğrulayıcı faktör analizi, asıl uygulama sonrası 78 öğrenci için bu 20 maddeye yönelik olarak gerçekleştirilmiştir.

\subsection{Veri Toplama}

Veriler, yukarıda da ifade edildiği gibi Hatay'da ikamet eden ve Türkçeyi yabancı dil olarak öğrenen öğrencilerden elde edilmiştir. Veri toplama sürecinde, geliştirilen ölçek katılımcılara uygulanmıştır. Ölçeğin katılımcılara sunulması için gerekli izinler alınmıştır. Ölçeğin katılımcılar tarafından doldurulması yaklaşı 10 dakika sürmüştür. Ölçek uygulaması, araştırmacı tarafından yönlendirilmiş ve uygulama öncesinde katılımcılara, katılımın gönüllülük esasına dayandığı, bu çalışmadan herhangi bir not verilmeyeceği ve elde edilecek verilerin yalnızca araştırma kapsamında kullanılacağ ifade edilmiştir.

\subsection{Verilerin Analizi}

Ölçek yoluyla katılımcılardan elde edilen veriler SPSS paket programı ile analiz edilmiştir. Elde edilen verilerin çözümlenmesinde, olumlu maddeler için "her zaman= 5, 
genellikle $=4$, bazen $=3$, nadiren $=2$ ve hiçbir zaman $=1$ " şeklinde puanlama yapılmıştır. Olumsuz maddeler ise ters çevrilerek puanlandırılmıştır. Ölçekte öncül olarak üç farklı faktör yaklaşımına dayalı bir madde havuzu oluşturulduğu için açımlayıcı faktör analizi esnasında "sabit faktör sayısı" üç olarak belirlenmiş ve döndürme tekniği olarak "varimax döndürme tekniği" kullanılmıştır. Bu faktörler, "yazmaya genel bakış", "yazmada yetersizlik" ve "yazmada yeterlilik" olarak adlandırılmıştır. Son olarak doğrulayıcı faktör analizi için LISREL programı kullanılmıştır.

\section{Bulgular}

Çalışmanın bu bölümünde deneysel süreç sonucunda elde edilen verilerin analizi ile ortaya çıkan bulgular sunulmuştur.

\subsection{Açımlayıcı Faktör Analizi}

“Yabancı Dil Olarak Türkçe Öğretiminde Yazma Becerisi Tutum Ölçeği”nin yap1 geçerliliğini belirlemek amacıyla, pilot uygulamadan elde edilen veriler açımlayıcı faktör analizi yöntemiyle çözümlenmiştir. Faktör analizinin mümkün olup olmadığını anlamak için KaiserMeyer-Olkin (KMO) değeri referans olarak alınmıştır. İlk analiz sonuçlarına göre ölçeğin KMO değeri .71 olarak bulunmuştur. KMO değerinin .70'den yüksek olması faktör analizi açısından "iyi" bir değer olarak kabul edilmektedir (Can, 2016, s. 325). Bu çalışmadan elde edilen KMO değerine göre örneklemin yeterli olduğunu ifade etmek mümkündür. Verilerin çok değişkenli normal dağılımdan gelip gelmediğini anlamak için veriler, Bartlett küresellik testi (Bartlett's test of sphericity) ile çözümlenmiş ve Bartlett küresellik testi sonucu anlamlı bulunmuştur $(\chi 2=$ 4.7603; $\mathrm{p}<0,01)$. Bartlett testinin anlamlı çıkması verilerin faktör analizi için uygun olduğunu ifade etmektedir. Bu nedenle elde edilen verilerin faktör analizi için uygun olduğu söylenebilir. $\mathrm{Bu}$ düşünceyle analizler tekrarlanarak devam etmiş, birden fazla faktörde yer alan ve faktör yükü değeri .30'un altında olan maddeler ölçme aracından çıkarılmışır. Sonuç itibariyle, 27 madde elendikten sonra faktör yükü değeri .49 ile .68 arasında değişen 20 madde ile ölçeğe son hali verilmiştir.

Ölçekte öncül olarak üç farklı faktör yaklaşımına dayalı bir madde havuzu oluşturulduğundan "sabit faktör sayısı" üç olarak belirlenmiş ve döndürme tekniği olarak "varimax döndürme tekniğii" kullanılmıştır. Bu faktörler, "yazmaya genel bakış", "yazmada yetersizlik" ve "yazmada yeterlilik" olarak adlandırılmıştır. 20 maddeden oluşan ölçeğin yedi maddesi $(4,8,10,11,15,17$ ve 18) yazmaya genel bakış, yedi maddesi $(2,3,6,12,16,19$ ve 20) yazmada yetersizlik ve altı maddesi $(1,5,7,9,13$ ve 14) yazmada yeterlilik faktörlerinin altında toplanmıştır. Her bir öğrencinin ölçekten alabileceği ağırlıklı ham puan en az 20 iken en fazla 100 'dür. Öğrencinin toplam puanının yüksek olması, onun yabancı dil olarak Türkçe yazmaya yönelik tutumunun olumlu olduğunun, düşük olması ise yabancı dil olarak Türkçe yazmaya yönelik tutumunun olumsuz olduğunun göstergesi olarak kabul edilmiştir. Pilot uygulamada, öğrencilerin "Yabancı Dil Olarak Türkçe Öğretiminde Yazma Becerisi Tutum Ölçeğì"nden elde ettikleri sonuçlara ilişkin yapılan analizlere ilişkin sonuçlar aşağıda sunulmuştur:

Tablo 1. Yabancı dil olarak Türkçe öğretiminde yazma becerisi tutum ölçeği açımlayıcı faktör analizinin özdeğer, varyans ve toplam varyansları

\begin{tabular}{lccc}
\hline Faktör & Özdeğer & Varyans $(\%)$ & Toplam varyans $(\%)$ \\
\hline 1- Yazmaya Genel Bakış & 3.654 & 18.271 & 18.271 \\
2- Yazmada Yetersizlik & 2.391 & 11.956 & 30.228 \\
3- Yazmada Yeterlilik & 1.933 & 9.666 & 39.893 \\
\hline
\end{tabular}

Tablo 1 incelendiğinde, 1 . faktör olan yazmaya genel bakış boyutunda toplam özdeğerin 3,654 olduğu; 2 . faktör olan yazmada yetersizlik boyutunda toplam özdeğerin 2,391 olduğu ve 3. faktör olan yazmada yeterlilik boyutunda ise toplam özdeğerin 1,933 olduğu anlaşılmıştır. Bu üç faktörün toplam varyansın \%39,89'unu (faktörlere göre sırasıyla; \%18,27, \%11,96, \%9,67) 
açıkladığı tespit edilmiştir. Kline (1994) faktör analizlerinde, faktör yüklerinin toplam varyansı açılama yüzdesinin 40'ın üzerinde olmasının kabul edilebilir olduğunu ifade etmiştir (akt. Cabı ve Yalçınalp, 2013, s. 90). Araştırmacı tarafından geliştirilen ölçeğin bu değere sahip olduğu düşünülebilir $(\% 39,89)$. Toplam varyansın en az \%50 olması gerektiğini ifade eden çalışmalar da bulunmaktadır ancak Williams, Onsman ve Brown (2012, s. 156)'a göre faktör analizinde toplam varyans, üzerinde uzlaşılamayan bir konudur. Yap1 farklılı̆̆ bulunduğu için toplam varyans için bir alt sınır belirlemek uygun değildir. Fen bilimlerinde yüksek varyans yüzdesi daha olasıyken, beşeri ve sosyal bilimlerde düşük varyans yüzdesi de kabul edilebilmektedir (Fatima, Ghayas ve Khawar, 2016, s. 5). Araştırmacı bu hususta karar verirken farklı kıstasları (ölçeğin güvenirliği, madde özdeğerleri, vb.) göz önünde bulundurmalıdır. Bununla birlikte, çalışma grubunun Türkçeyi yabanc1 dil olarak öğrenen öğrencilerden oluşması da toplam varyansın biraz düşük çıkmasına yol açmış olabileceği düşünülebilir. Bu doğrultuda değerlendirme yapılmıştır. Aşağıdaki tabloda, ölçekte yer alan maddelerin döndürülmüş (rotated) faktör yükleri yer almaktadır.

Tablo 2. Yabancı dil olarak Türkçe öğretiminde yazma becerisi tutum ölçeği açımlayıcı faktör analizi sonuçları

\begin{tabular}{|c|c|c|c|}
\hline \multirow[t]{2}{*}{ Maddeler } & \multicolumn{3}{|c|}{$\begin{array}{l}\text { Döndürülmüş faktör } \\
\text { yükleri }\end{array}$} \\
\hline & F1 & $\mathrm{F} 2$ & F3 \\
\hline 4 Türkçe yazdı̆̆ım zaman sıkılırım. & .624 & & \\
\hline 8 Türkçe yazı yazabildiğim zaman çok mutlu olurum. & 620 & & \\
\hline 10 Türkçe yazmak gereksizdir. & .603 & & \\
\hline 11 Türkçe yazmak Türkçe konuşmamı kolaylaştırır. & .523 & & \\
\hline 15 Türkçe yazmaktan nefret ederim. & .614 & & \\
\hline 17 Yazı yazarak Türkçemin daha iyi olacağına inanırım. & .631 & & \\
\hline 18 Türkçe yazdığım zaman, onu tekrar okur ve hatalarımı düzeltirim. & .658 & & \\
\hline 2 Türkçe yazarken fikirlerimi ifade etmek benim için zordur. & & .545 & \\
\hline 3 Öğretmenim Türkçe yazmamı istediğinde stres yaşarım. & & .507 & \\
\hline 6 Türkçe yazmak için kendimi çok zorlamam gerekir. & & .530 & \\
\hline 12 Türkçe yazmak isterim ama hata yapmaktan korkarım. & & .665 & \\
\hline $\begin{array}{l}16 \text { Bir konu hakkında Türkçe yazmak istediğim zaman aklıma hiçbir şey } \\
\text { gelmez. }\end{array}$ & & .689 & \\
\hline 19 Türkçe yazarken çok fazla hata yaparım. & & .660 & \\
\hline 20 Bir konuda, nasıl Türkçe yazacağımı bilmem. & & .666 & \\
\hline 1 Türkçe yazmayı severim. & & & .499 \\
\hline 5 Gün içinde yaptıklarımı bir deftere veya günlüğe Türkçe yazarım. & & & .571 \\
\hline 7 Boş vaktim olduğu zaman Türkçe yazmak isterim. & & & .598 \\
\hline 9 Çok sevdiğim bir film veya kitap hakkında fikirlerimi Türkçe yazarım. & & & .631 \\
\hline 13 Aileme veya arkadaşlarıma Türkçe mektup veya notlar yazarım. & & & .523 \\
\hline 14 Yapacağım işleri unutmamak için Türkçe notlar almak hoşuma g & & & .633 \\
\hline
\end{tabular}

Tablo 2 incelendiğinde "Yabancı Dil Olarak Türkçe Öğretiminde Yazma Becerisi Tutum Ölçeği" maddelerinin faktör yüklerinin .49 ile .68 arasında değiştiği anlaşılmıştır. Diğer taraftan, ölçeğin güvenirliğini test etmek için Cronbach's Alpha güvenirlik katsayısına bakılmış ve ölçeğin tamamı için Cronbach's Alpha güvenirlik katsayısı $\alpha=.653$ olarak bulunmuştur. Güvenirlik katsayısı, -1 ile +1 arasında değişen değerler alabilmektedir. $\mathrm{Bu}$ değer +1 'e yaklaştıkça ölçeğin güvenilirliği artmaktadır (Can, 2016, s. 388). Özdamar (1999), 0.60 ile 0.90 arasındaki Cronbach's Alpha güvenirlik katsayısının, ölçeğin oldukça güvenilir olduğunu gösterdiğini ifade etmiştir (akt. Tavşancıl, 2006, s. 29). Bu sebeple araştırmacı tarafindan geliştirilen ölçeğin oldukça güvenilir olduğunu ifade etmek mümkündür $(\alpha=.653)$. Açımlayıcı faktör analizinden sonra kalan 20 maddeye ilişkin doğrulayıcı faktör analizi yapılmıştır. Doğrulayıcı faktör analizine ilişkin sonuçlar aşağıda verilmiştir. 


\subsection{Doğrulayıcı Faktör Analizi}

Açımlayıcı faktör analizi yoluyla ortaya çıkan model yapısını test etmek amacıyla doğrulayıcı faktör analizi uygulanmıştır. Bu şekilde, 3 faktör ve 20 maddeden oluşan ölçeğin yap1 geçerliği incelenmiştir. Bu doğrultuda, $\chi 2 / d f$ (Chi-Square/Degree of Freedom), RMSEA (Root Mean Square Error of Approximation), SRMR (Standardized Root Mean Square Residual), NNFI (Non-Normed Fit Index), GFI (Goodness of Fit Index), CFI (Comparative Fit Index), PNFI (Parsimony Normed Fit Index) ve TLI (Tucker-Lewis Index) değerlerine bakılmıştır. Uyum indeks değerleri, kurulan model içerisinde 1 maddenin çalışmadığını göstermiştir. "Türkçe yazmayı severim." şeklindeki bu madde (1. madde), uyum değerlerini olumsuz yönde etkilediği için doğrulayıcı faktör analizi esnasında kullanılmamıştır. Doğrulayıcı faktör analizi esnasında kullanılmasa da araştırmacı, ilgili maddenin ölçekten atılmasının uygun olmayacağını düşünerek ölçekte kalmasına karar vermiştir. Doğrulayıcı faktör analizi sonucunda Chi Square (Ki Kare) / df değeri 190.852 / 146= 1.31, RMSEA değeri 0.047 olarak hesaplanmıştır. Yapılan doğrulayıcı analiz sonucu elde edilen modele ait uyum değerleri Tablo 3’te verilmiştir.

Tablo 3. Doğrulayıcı faktör analizi madde boyutları uyum modeli değerleri

\begin{tabular}{cccc}
\hline $\begin{array}{c}\text { Uyum } \\
\text { Kriteri }\end{array}$ & Mükemmel Uyum Değerleri & Kabul Edilebilir Değerler & $\begin{array}{c}\text { Ölçekten Elde Edilen Uyum } \\
\text { Değerleri }\end{array}$ \\
\hline$\chi^{2} / \mathrm{df}$ & $0 \leq \chi^{2} / d \mathrm{f} \leq 3$ & $\chi^{2} / d \mathrm{f} \leq 5$ & $\chi^{2} / d \mathrm{f}=1.31$ \\
\hline RMSEA & $0 \leq \mathrm{RMSEA} \leq 0.05$ & $\mathrm{RMSEA} \leq 0.08$ & $\mathrm{RMSEA}=0.047$ \\
\hline SRMR & $0 \leq \mathrm{SRMR} \leq 0.05$ & $\mathrm{SRMR} \leq 0.10$ & $\mathrm{SRMR}=0.077$ \\
\hline NNFI & $>0.95$ & $>0.90$ & 0.91 \\
\hline GFI & $>0.95$ & $>0.90$ & 0.88 \\
\hline CFI & $>0.95$ & $>0.90$ & 0.92 \\
\hline PNFI & $0.95 \leq \mathrm{PNFI} \leq 1.00$ & $0.50 \leq \mathrm{PNFI} \leq 0.95$ & 0.64 \\
\hline TLI & $0.95 \leq \mathrm{TLI} \leq 1.00$ & $0.50 \leq \mathrm{TLI} \leq 0.95$ & 0.91
\end{tabular}

Tablo 3'teki uyum değerleri incelendiğinde, ölçeğin $x^{2} / d f$ ve RMSEA değerleri bakımından mükemmel; SRMR, NNFI, CFI, PNFI ve TLI değerleri açısından ise kabul edilebilir uyuma sahip olduğu anlaşılmaktadır. GFI değeri ise 0.88 olarak hesaplanmıştır. $\mathrm{Bu}$ değer, genel olarak kabul gören minimum değerin (0.90) altındadır. Büyüköztürk vd. (2004, s. 234), GFI değerinin 0.85 olmasının dahi bazı araştırmacılar tarafından kabul edilebilir olduğunu ifade etmiş̧ir. Buradan yola çıkarak bu çalışmada elde edilen GFI değerinin de kabul edilebilir olduğunu öne sürmek yanlış olmayacaktır. GFI değerinin az da olsa düşük çıkmasını örneklem büyüklüğü ile açıklamak da mümkün olabilir. Nitekim Anderson ve Gerbing'e (1984, s. 166) göre örneklem sayısı arttıkça GFI değeri yükselmektedir. Yapılan analizler neticesinde ortaya çıkan diyagram Şekil 1'de verilmiştir. 
Şekil 1. YDO-TÖYBT ölçeğinin doğrulayıcı faktör analizinin standartlaştırılmış değerleri

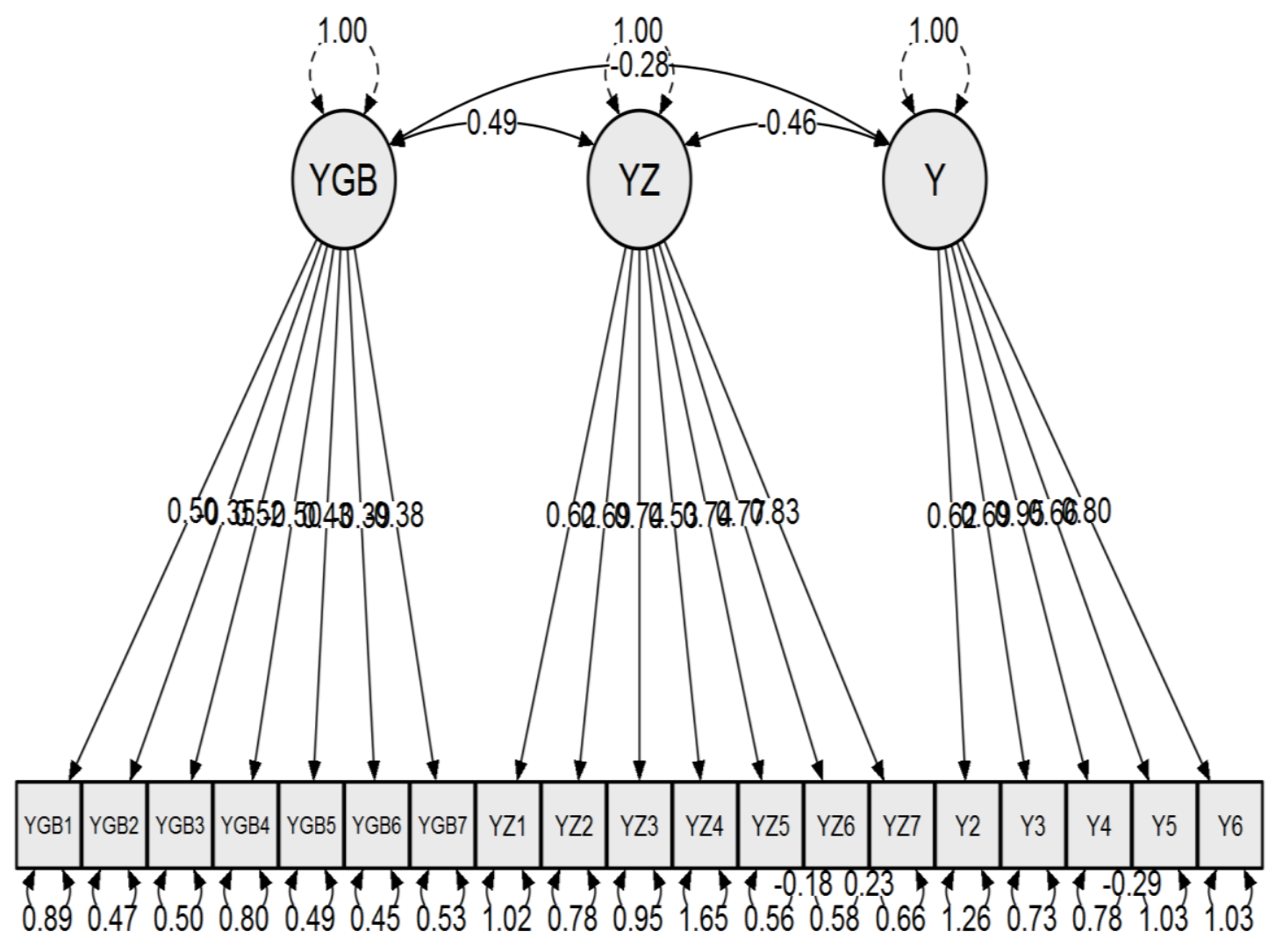

YGB: Yazmaya Genel Bakış $\quad$ YZ: Yazmada Yetersizlik $\quad$ Y: Yazmada Yeterlilik

\section{Tartışma, Sonuç ve Öneriler}

Bu çalışmada, Türkçeyi yabancı dil olarak öğrenen öğrencilerin Türkçe yazmaya yönelik tutumlarını ölçmek amacıyla geçerlik ve güvenirlik çalışmaları yapılmış bir ölçme aracının geliştirilmesi amaçlanmıştır. Bu amaç doğrultusunda, Türkçeyi yabancı dil olarak öğrenen 377 öğrenci ile çalışma gerçekleştirilmiştir. Ölçeğin geliştirilebilmesi için ilk olarak konuya ilişkin literatür taraması yapılmıştır. Literatür taraması neticesinde, 50 maddeden oluşan taslak ölçek elde edilmiştir. Taslak ölçek, görüşlerini alabilmek amaciyla Türkçe eğitimi alanında çalışan ve TÖMER tecrübesi bulunan 3 alan uzmanı ile ölçme ve değerlendirme alanında çalışan 2 alan uzmanına sunulmuştur. Uzman görüşleri doğrultusunda ölçekteki 3 madde atılmış ve madde sayısı 47 olmuştur. Diğer taraftan, ölçekteki 4 madde, anlam karmaşasına yol açabileceği ihtimaliyle uzman görüşleri doğrultusunda ifade olarak düzeltilmiştir. Bu şekilde ölçeğin kapsam ve görünüş geçerliği sağlanmıştır. Ölçek, 5'li Likert şeklinde yapılandırılmıştır.

Geliştirilen ölçeğin yapı geçerliğini test edebilmek amacıyla açımlayıcı faktör analizi ve bunun ardından elde edilen yapıyı doğrulayabilmek amacıyla doğrulayıcı faktör analizi yapılmıştır. Ölçeğin taslak maddeleri $(\mathrm{n}=50)$ üzerinden yapılan açımlayıcı faktör analizi sonucunda, 20 madde ve üç faktörden oluşan ölçek elde edilmiştir. Üç faktörün toplam varyansın \%39,89'unu açıkladığı belirlenmiştir. Faktörler, ölçekteki maddelerin kapsam ve özelliklerine göre adlandırılmıştır. Bu doğrultuda, birinci faktöre "yazmaya genel bakış", ikinci faktöre "yazmada yetersizlik" ve üçüncü faktöre "yazmada yeterlilik" şeklinde isimler verilmiştir. Açımlayıcı faktör analizi ile 20 maddeden oluşan ölçeğin son hali, doğrulayıcı faktör analizi ile test edilmiştir. Doğrulayıcı faktör analizi sonucunda, ortaya çıkan yapının genel anlamda kabul edilebilir düzeyde uyumlu olduğu ve test edilen modelin doğrulandığı 
anlaş1lmıştır $\left(\chi^{2} / \mathrm{sd}=1.31 ; \mathrm{RMSEA}=.047 ; \mathrm{SRMR}=.077 ; \mathrm{NNFI}=.91 ; \mathrm{GFI}=.88 ; \mathrm{CFI}=.92 ; \mathrm{TLI}=\right.$ $.91)$.

Diğer taraftan ölçeğin, en önemli özelliklerden biri olan güvenirliğe sahip olup olmadığını belirleyebilmek amacıyla Crombach's Alfa güvenirlik katsayısı hesaplanmış ve $\alpha=.653$ olarak bulunmuştur. Güvenirlik katsayısı, -1 ile +1 arasında değişen değerler alabilmektedir. Bu değer +1'e yaklaştıkça ölçeğin güvenilirliği artmaktadır (Can, 2016, s. 388). Özdamar (1999), 0.60 ile 0.90 arasındaki Cronbach's Alpha güvenirlik katsayısının, ölçeğin oldukça güvenilir olduğunu gösterdiğini ifade etmiş̧tir (akt. Tavşanc1l, 2006, s. 29). Bu nedenle araştırmacı tarafından geliştirilen ölçek oldukça güvenilir şeklinde yorumlanmıştır ( $\alpha=.653)$.

Tutum, bir insanın herhangi bir konudaki eğilimleri, duyguları, önyargıları, önceden şekillenmiş düşünceleri, korkuları, tehditleri ve inançlarının genel toplamıdır (Thurstone, 1928, s. 531). Bu nedenle bireylerin herhangi bir şeye yönelik tutumlarını ölçmek, ilgili şeyde gelişim sağlanabilmesi açısından gereklidir. Bireylerin tutumlarını ölçmenin en kolay yolu tutum ölçeklerinden faydalanmaktır. Genel olarak yazmaya yönelik (Akaydın ve Kurnaz, 2015; Graham, Berninger ve Fan, 2007; Susar Kırmızı, 2009; Temizkan ve Sallabaş, 2009; Uygun, 2012) ve yabancı dil olarak İngilizce yazmaya yönelik (Okasha ve Hamdi, 2014; Öztürk, 2019) geliştirilmiş olan birçok tutum ölçeği bulunmaktadır. Fakat literatürde yabancı dil olarak Türkçe yazmaya yönelik herhangi bir ölçeğe rastlanmamıştır. Türkçeyi yabancı dil olarak öğrenenlerin sayısındaki artış düşünüldüğünde böyle bir ölçeğe ne kadar ihtiyaç duyulduğu daha net anlaşılabilir. Özellikle, hedef dilde yazmayı sadece duyuşsal sebeplerle karmaşık bulan öğrencilerin tespiti için bu ölçeğin çok faydalı olacağına inanılmaktadır. Hem TÖMER'lerde hem de Türkçenin yabancı dil olarak öğretildiği tüm kurumlarda çalışan eğitimcilerin bu ölçeği kullanarak öğrencilerin yazmaya yönelik tutumlarını belirleyeceği ve bu şekilde tutumları düşük olan öğrencilere yönelik çalışmalar yapabileceği düşünülmektedir.

\section{Kaynakça}

Abbas, S. H. (2016). The effect of reflection-supported process-based writing teaching on Iraqi EFL students' writing performance and attitude. Arab World English Journal (AWEJ), 7(4), 42-62.

Akaydın, Ş. ve Kurnaz, H. (2015). Lise öğrencilerine yönelik yazma tutum ölçeği: Geçerlik ve güvenirlik çalışması. Mustafa Kemal Üniversitesi Sosyal Bilimler Enstitüsü Dergisi, 12(32), 246-261.

Akbulut, S. (2016). Yabancı dil olarak Türkçe ögrenenlerin yazmaya yönelik tutum ve kaygıları (Yayımlanmamış yüksek lisans tezi). Pamukkale Üniversitesi Eğitim Bilimleri Enstitüsü, Denizli.

Anderson, J. C., \& Gerbing, D. W. (1984). The effect of sampling error on convergence, improper solutions, and goodness-of-fit indices for maximum likelihood confirmatory factor analysis. Psychometrika, 49(2), 155-173.

Aytan, N. ve Tunçel, H. (2015). Yabanc1 dil olarak Türkçe yazma kaygısı ölçeği. Mustafa Kemal Üniversitesi Sosyal Bilimler Enstitüsü Dergisi, 12(30), 50-62.

Balcı, A. (2009). İlköğretim 8. sınıf öğrencilerinin kitap okuma alışkanlığına yönelik tutumları. Mustafa Kemal Üniversitesi Sosyal Bilimler Enstitüsü Dergisi, 6(11), 265-300.

Bölükbaş, F. (2011). Arap öğrencilerin Türkçe yazılı anlatım becerilerinin değerlendirilmesi. Turkish Studies, 6(3), 1357-1367.

Brown, G., Manogue, M., \& Rohlin, M. (2002). Assessing attitudes in dental education: Is it worthwhile?. British Dental Journal, 193(12), 703-707. https://doi.org/10.1038/sj.bdj.4801665 
Büyüköztürk, Ş. (2005). Anket geliştirme. Türk Eğitim Bilimleri Dergisi, 3(2), 133-151.

Büyüköztürk, Ş., Akgün, Ö. E., Özkahveci, Ö. ve Demirel, F. (2004). The validity and reliability study of the Turkish version of the motivated strategies for learning questionnaire. Kuram ve Uygulamada Eğitim Bilimleri, 4(2), 231-239.

Cabı, E. ve Yalçınalp, S. (2013). Öğretmen adaylarına yönelik mesleki kaygı ölçeği (MKÖ): Geçerlik ve güvenirlik çalışması. Hacettepe Üniversitesi Eğitim Fakültesi Dergisi, 44, 85-96.

Can, A. (2016). SPSS ile bilimsel araştırma sürecinde nicel veri analizi (4. Baskl). Ankara: PEGEM Akademi.

Davis, K. (1987, May1s). Improving students' writing attitudes: The effects of the writing center. Paper presented at the Proceedings of the Annual Meeting of the East Central Writing Center Association, Youngstown: ERIC. https://files.eric.ed.gov/fulltext/ED294183.pdf linkinden erişilmiş̧tir.

Elshirbini, I. (2013). The effect of the genre-based approach to teaching writing on the EFL Alazhr secondary students' writing skills and their attitudes towards writing. Recuperado el, 28.

Erarslan, A. (2011). Pamukkale Üniversitesi Yabancı Diller Yüksekokulu hazırlı sinıf ögrencilerinin yazma dersine karşı algı ve tutumları ve yazma dersindeki tutum-başarı ilişkisinin incelenmesi (Yayımlanmamış yüksek lisans tezi). Pamukkale Üniversitesi, Denizli.

Erdem, D. (2007). A study of developing an attitude scale toward an English course. Eurasian Journal of Educational Research, 7(28), 45-54.

Erdoğan, Ö. (2012). Süreç temelli yaratıcı yazma uygulamalarının yazılı anlatım becerisine ve yazmaya ilişkin tutuma etkisi (Yayımlanmamış doktora tezi). Hacettepe Üniversitesi Sosyal Bilimler Enstitüsü, Ankara.

Erdoğan, T. (2013). The effect of creative drama method on pre-service classroom teachers' writing skills and attitudes towards writing. Australian Journal of Teacher Education, 38(1), 45-61. http://dx.doi.org/10.14221/ajte.2013v38n1.5

Fatima, A., Ghayas, S., \& Khawar, R. (2016). Development and validation of alexithymia scale for Pakistani population. Pakistan Journal of Social and Clinical Psychology, 14(2), 3-9.

Fosnot, C. T. (1989). Enquiring teachers, enquiring learners: A constructivist approach for teaching. New York: Teachers College Press.

Göçer, A. (2010). Türkçe öğretiminde yazma eğitimi. Uluslararası Sosyal Araştırmalar Dergisi, 3(12), 178-195.

Göçer, A. (2012). Türkçe öğretmen adaylarının yetizleme çalışmalarıyla oluşturdukları metinlerin metinlerarasılık: dilsel metinlerin kullanımı açısından incelenmesi. Uluslararası Online Eğitim Bilimleri Dergisi, 4(1), 184-195.

Göçer, A. (2014). Yazma eğitimi. Ankara: Pegem Akademi Yayıncılık.

Graham, S., Berninger, V., \& Abbott, R. (2012). Are attitudes toward writing and reading separable constructs? A study with primary grade children. Reading \& Writing Quarterly, 28(1), 51-69.

Graham, S., Berninger, V., \& Fan, W. (2007). The structural relationship between writing attitude and writing achievement in first and third grade students. Contemporary Educational Psychology 32, 516-536.

Güneş, F. (2007). Türkçe öğretimi ve zihinsel yapılandırma. Ankara: Nobel Yayıncılık. 
Hess, M., \& Wheldall, K. (1999). Strategies for improving the written expression of primary children with poor writing skills: A sociocognitive perspective. Australian Journal of Learning Difficulties, 4(4), 14-20.

Hillson, D., \& Murray-Webster, R. (2004, November). Understanding and managing risk attitude. In Proceedings of 7th Annual Risk Conference, held in London, UK (Vol. 26).

Karakoç, F. Y. ve Dönmez, L. (2014). Ölçek geliştirme çalışmalarında temel ilkeler. Tip Eğitimi Dünyası, 40, 39-49.

Kear, D. J., Coffman, G. A., McKenna, M. C., \& Ambrosio, A. L. (2000). Measuring attitude toward writing: A new tool for teachers. The Reading Teacher, 54(1).

Lewis, R. B. (1998). Enhancing the writing skills of students with learning disabilities through technology: an investigation of the effects of text entry tools, editing tools, and speech synthesis. final report. Washington: ERIC. https://files.eric.ed.gov/fulltext/ED432117.pdf linkinden erişilmiştir.

O'neal, M. R., Guttinger, H. I., \& Morris, C. M. (1984, Kasım). Validation of a writing attitude scale. Paper presented at the Annual Meeting of the Mid-South Educational Research Association, New Orleans, LA: ERIC. https://files.eric.ed.gov/fulltext/ED252577.pdf linkinden erişilmiştir.

Okasha, M. A., \& Hamdi, S. A. (2014). Using strategic writing techniques for promoting EFL writing skills and attitudes. Journal of Language Teaching and Research, 5(3), 674-681.

Öztürk, Ö. (2019). Personal goal-setting in an EFL writing class. Dil Dergisi, 170(1), 89-107.

Prickel, D. O. (1995). The development and validation of a writing self-efficacy scale for adult basic writers and its use in correlational analysis (Yayımlanmamıs doktora tezi). Oregon State University, Education.

Soltani, A., \& Kheirzadeh, S. (2017). Exploring EFL students' use of writing strategies and their attitudes towards reading-to-write and writing-only tasks. Journal of Language and Linguistic Studies, 13(2), 535-560.

Susar Kırmızı, F. (2009). Türkçe dersinde yaratıcı drama yöntemine dayalı yaratıcı yazma çalışmalarının yazmaya yönelik tutuma etkisi. Yaratıcı Drama Dergisi, 4(7), 51-68.

Tavşancıl, E. (2006). Tutumların Ölçülmesi ve SPSS ile Veri Analizi. Ankara: Nobel Yayıncılık.

Temel, S. ve Katrancı, M. (2019). İlkokul öğrencilerinin yazılı anlatım becerileri, yazmaya yönelik tutumları ve yazma kaygıları arasındaki ilişki. Avrasya Uluslararası Araştırmalar Dergisi, 7(17), 322-356.

Temizkan, M. (2018). Yazma eğitimi. Bilginer Onan ve M. Onur Kan (Ed.), Illk okuma yazma ve Türkçe öğretimi içinde (ss. 143-211). Ankara: Nobel Yayıncılık.

Temizkan, M. ve Sallabaş, M. E. (2009). Öğretmen adaylarının okuma ve yazmaya yönelik tutumlarının karş1laştırılması. Elektronik Sosyal Bilimler Dergisi, 8(27), 155-176.

Tezbaşaran, A. (2008). Likert tipi ölçek hazırlama kılavuzu (Üçüncü sürüm e-kitap). Mersin, ISBN: 975-9756-08-5.

Thomas, D. L. (1989). The effects of freewriting on high school students' attitudes toward writing (Yayımlanmamış yüksek lisans tezi). University of North Florida, College of Education and Human Services. http://digitalcommons.unf.edu/etd/41 linkinden erişilmiştir.

Thurstone, L. L. (1928). Attitudes can be measured. The American Journal of Sociology, 33, $529-554$. 
Tiryaki, E. N. (2013). Yabancı dil olarak Türkçe öğretiminde yazma eğitimi. Ana Dili Eğitimi Dergisi, 1(1), 38-44.

Türkel, A. (2011). Yaratıcı dramanın yaratıcı yazma başarısına ve yazmaya karşı tutuma etkisi (İlkögretim 8. Sınıf) (Yayımlanmamış doktora tezi). Dokuz Eylül Üniversitesi: İzmir.

Türkel, A. (2013). Yaratıcı dramanın yaratıcı yazma başarısına ve yazmaya karşı tutuma etkisi (Ortaokul 8. sınıf örneği). Buca Ĕ̆itim Fakültesi Dergisi, 36, 1-11.

Uygun, M. (2012). Öz düzenleme stratejisi gelişimi öğretiminin yazıll anlatıma, yazmaya yönelik öz düzenleme stratejisine, kalıcılığa ve tutuma etkisi (Yayımlanmamış doktora tezi). Hacettepe Üniversitesi, Ankara.

Wasson, K. L. (1993). Implementation of a publishing center to enhance the writing process for prımary students (Yayımlanmamış yüksek lisans tezi). Nova University, Faculty of the Center for Advancement of Education.

Williams, B., Onsman, A., \& Brown, T. (2012). A rasch and factor analysis of a paramedic graduate attribute scale. Evaluation \& the Health Professions, 35(2), 148-168.

Wynn, E. S., Cadet, L. P., \& Pendleton, E. P. (2000). A model for teaching writing: socially designed and consensus oriented. https://files.eric.ed.gov/fulltext/ED446701.pdf linkinden erişilmiştir.

Yurdugül, H. (2005). Ölçek geliştirme çalışmalarında kapsam geçerliği için kapsam geçerlik indekslerinin kullanılması. XIV. Ulusal Eğitim Bilimleri Kongresi, 1, 771-774.

\section{ETIKK ve BİLIMSEL İLKELER SORUMLULUK BEYANI}

$\mathrm{Bu}$ çalışmanın tüm hazırlanma süreçlerinde etik kurallara ve bilimsel atıf gösterme ilkelerine riayet edildiğini yazar(lar) beyan eder. Aksi bir durumun tespiti halinde Afyon Kocatepe Üniversitesi Sosyal Bilimler Dergisi'nin hiçbir sorumluluğu olmayıp, tüm sorumluluk makale yazarlarına aittir. Yazarlar etik kurul izni gerektiren çalışmalarda, izinle ilgili bilgileri (kurul adı, tarih ve sayı no) yöntem bölümünde ve ayrıca burada belirtmişlerdir.

Kurul adı: Hatay Mustafa Kemal Üniversitesi Sosyal ve Beşeri Bilimler Bilimsel Araştırma ve Yayın Etiği Kurulu

Tarih: 02.08.2018

No: $10 / 01$

\section{ARAŞTIRMACILARIN MAKALEYE KATKI ORANI BEYANI}

1. yazar katkı oranı : $\% 70$

2. yazar katkı oranı : \% 30 